\title{
Specific (Blocked) Post-socialist Union Transformation in Serbia
}

\author{
Mirjana Bobić \\ Associate Professor, University of Belgrade, Faculty of Philosophy, Belgrade, \\ Serbia \\ e-mail:matildab@eunet.rs
}

\begin{abstract}
This paper is a reflection on stalled union transformation in Serbia in the context of post-socialist transition. The empirical evidence is based on official statistics and representative sociological research on cohabitations and families since 2000 . The aim is to describe some general tendencies and to suggest possible ways of interpreting field results. The paper first introduces the analytical framework, consisting of two main theories/paradigms - a (specific) second demographic transition (SDT) and deprivation (POD). Through exploring and combining different sources of evidence, we try to cast more light on specific, blocked or very slow individualization in Serbia. The main conclusion is that some changes might be identified such as: delayed union formation along with postponed childbearing for a vast majority of population, followed by a striking increase in extramarital births ever since the 1990s. The latter is particularly prominent among younger and disadvantaged women (less educated, lower social positions, from rural areas and small towns), who are, however, neither married nor cohabiting. On the other hand, transition into adulthood of young adults is protracted. Structural and institutional barriers hamper their behavioral choices as well as the pluralization of living arrangements, which is evident among their counterparts throughout developed Europe and ex-Yugoslavia, with Slovenia excluded. Instead, patriarchy and strong kinship based solidarity persist in conditions of long lasting economic turmoil, low living standards and delayed European integrations.
\end{abstract}

Key words: unions, Serbia, post socialist transition, young adults, kinship based solidarity.

\section{Introduction: Changes in partnership and family behavior}

During the last 10-20 years basic trends in union formation have been converging throughout Europe and the developed world and they are reflected in: decline of marriage and fertility rates, followed by greater social acceptance of alternative living arrangements, such as LATs ('living apart together') ${ }^{1}$, cohabitations (either as a

$\mathbf{1}$ LAT is close to 'steady dating' (Sobotka and Toulemon, 2008), referring to intimate couples who do not share dwelling. 
prelude to marriage, post divorce form or marginal phenomenon), etc, all of which have produced pluralization of living arrangements, facilitated by 'destandardization' in transitions into adulthood and reflexive ('do it yourself' biographies), (Beck, Giddens, Corijn and Klijzing, 2001). Not only has the entry into marriage been delayed, but greater family instability has occurred as well (increased divorce and remarriage), with rising shares of young couples without children, singles, step parenthood, post-familial forms, reconstituted unions, etc (Pongratz and Spéder, 2008, Sobotka and Toulemon, 2008, Sobotka, 2008, Roseneil and Budgeon, 2004).

However, despite the convergence in behavior towards partnership and family, there is also evidence of persisting differences among European countries, in line with geopolitical divisions, diverse historical background and cultural features, social hierarchies, welfare states, cohorts' effects, etc (Kuijsten, 1996, Boh, 1987). A steep fall in total first marriage rates, accompanied by an increase in mean age of entry into unions and widely spread cohabitations, with rising shares of children born in these unions, first occurred in the 1960s in Northwestern Europe, disseminated to the Western part in the 1970s, and only in the 1990s emerged both in Southern Europe and in the countries of post-socialist transition. Extramarital childbearing typically started within disadvantaged social groups and was afterwards adopted by higher social strata (Perelli - Harris et al, 2010, Perelli - Harris and Gerber, 2011), but vice versa, as well. Namely, in some regions and countries (in Northern Europe) it was initiated by urban intelligentsia (young adults, higher educated, opting for liberal views, gender equality, minority rights etc), (Prinz, 1995, Lestheaghe, Neidert, Surkyn, 2006, etc), who were trendsetters and then was adopted by lower strata or from central urban areas towards inner parts of a country.

Despite the decline in universality of marriage, the vast majority of population even in countries depicted as forerunners (like Sweden) still perceive conjugal union as an end goal and optimal life style (Oláh and Bernhardt, 2008). Marriage has nevertheless lost its significance as the marker of transition into adulthood, delineation of relationships between men and women, source of personal identity, and the prerequisite for reproduction (Sobotka and Toulemon, 2008; Kuhar and Reiter, 2010). Greater sexual freedom for young adults, their increased mobility, rights to privacy granted in parental home, elevated wellbeing of parents' household, higher social tolerance towards alternative living arrangements, prolonged the transition into adulthood, due to higher and longer education and investment in personal human capital, combined with tight labor market opportunities, all of these have both weakened the pressure for leaving parental home and reinforced the differentiation of patterns of family formation and partnership behavior across Europe (ibidem). So called de-standardization of transition into adulthood in terms of early separation from parents' household, frequent cohabitation and LAT in their 20s and early 30s, late start of family formation is more pronounced in Northern and Western regions, while in countries of Southern Europe and those in post socialist transformation, a model of protracted transition and entry into marriages directly, i.e. while living with family of procreation is more pronounced (Poland, Czech Republic, Slovakia, Balkan States, ex Soviet Republics, etc). 
When speaking about Serbia, demographic trends in union formation are similar to the EU - 27, with decline of marriage universality and fall of fertility ever since the 1970s, the trends that have been even more salient since the beginning of the post-socialist transition in the 1990 and since 2000. However, divorces are rare and only in recent years an increase in their number and ratio have been registered (Kuhar and Reiter, 2010), the trend which has been explained through the 'crisis' argument. Namely, conserving (current) unions and avoiding their dissolution have been identified as a coping strategy aimed at combating the hardships of everyday living related to prolonged and still uncompleted social transformation into market economy (job losses and high unemployment, massive impoverishment of population, low levels of economic and social capital of individuals and families, social disorganization, corruption and criminalization, particularly in the 1990s, etc), (Milić et al, 2004; Bobić, 2004). Families of procreation and orientation are highly interdependent, which is also the case in Southern Europe and is intertwined with poor welfare state and low level of state support to (young) people (Di Giulio, and Rosina, 2007; Kuhar and Reiter, ibidem). As many as one out of three households in Serbia contain more than one nuclear family (with one or both parents living with married children, or a divorced child, or married siblings living together, etc). This trend towards family re-unification and re-enforcement particularly since 1991 has also been interpreted as a part of a coping strategy in a country whose population has faced severe pauperization due to economic restructuring, sharp decline of quality of livelihood ${ }^{2}$, political turmoil and delayed integration into the global economy (Milić et al, 2005; Milić et al, 2010)².

At the same time, non-marital births have increased significantly (from 8\% in 1950 to $13.1 \%$ in 1990 up to $22.8 \%$ in 2008), (Penev and Stanković, 2010a and 2010b) although not as strongly as in some other transitional countries, e.g. Slovenia (see Kuhar and Reiter, 2010). Namely, in the same period in Slovenia these shares increased from 24.5\% to 52.8\%, in Hungary from 13.1\% to 39.5\% and in Bulgaria from $12.4 \%$ to $51.1 \%$. Serbia is similar to Poland (rise from $6.2 \%$ to $19.9 \%$ ), Moldova (from $11.1 \%$ up to $22.3 \%$ ), Russia (14.6\% in 1990 to $26.9 \%$ in 2008 ) and Ukraine (11.2\% to 20.9\%). When compared to the EU countries, the increase in Serbia can be assessed as similar to: Italy, Spain and Portugal (in 1990, 6.3\%, 9.6\% and 14.7\% respectively while in 2008, the following increase has been evidenced: 17.7\% (2007 in Italy), in Spain 31.7\% and in Portugal 33.6\% (2008) (Stanković and Penev, 2010a:17).

However, while in the majority of developed European countries, extramarital births occur within cohabitations, in Serbia, on the contrary, a vast majority of these children live within single parent families. Cohabitations are very rare in Serbia, representing as few as 1.6-2\% of all households (RZS; Bobić, 2006, 2012; Stanković and

2 Today Serbia still has not reached GDP from 1989. Before economic crisis in 2008 it approached to the level of $80 \%$ (Petrović, 2011)

3 These findings on extended families, their relationships, the position of young families therein, gender roles, etc, have been broadly discussed by local researchers (Miletić-Stepanović, V., 2011). 
Penev, 2010a and 2010b; Tomanović, S., et al, 2012). Among the countries of exYugoslavia, Slovenia is the only one where extramarital births are high and tightly related to cohabitation, while the average share of these extra-marital unions in the region as a whole is as few as 4\% (Kuhar and Reiter, 2010). Nonetheless in other countries of post-socialist transformation the share of cohabitating households is higher: in Estonia, in the age groups: $25-29$ and 30-34 (41.4.\% and 28.07\%), in Slovenia (27.1 and 17.2\% respectively), in Hungary (21.2 and $12.7 \%$ ), in Romania (11.5 and $7.8 \%)$ while they are lower in the Czech Republic (8.7\% and 5.7\%), Poland (4.4 and 2.5\%) and Slovakia (3.7 and 2.9\%), (Pongracz and Spéder, 2008).

Sociological surveys, carried out in 2003 and 2007 by the Institute for Sociological Research of the Faculty of Philosophy in Belgrade (Milić, et al, 2004, 2005, 2010; Bobić, 2006; Petrović, 2010), indicated that single mothers (whether divorced and/ or unmarried) most frequently reside within complex family households, therefore leaning onto parents' and relatives' support and their multiple resources, economic and social capitals (33\% and $32.4 \%$ respectively).

Therefore the question arises as to how these developments of conserving and reinforcing the family on the one hand and the emergence of single motherhood on the other, could be interpreted ${ }^{4}$ ? Another reason to study the Serbian case is to shed more light since the country has yet not been encompassed by any of the great surveys carried out recently, such as FFS or GGS5. This paper will first introduce the theoretical framework that seems most relevant for further interpretation of empirical evidence in Serbia. In the next part a secondary analysis of field data of two major sociological surveys and referent demographic study of extramarital childbearing will be presented. A special attention will be paid to value orientations of the younger and older couples in order to try to illuminate the shifts in attitudes on the continuum conservativism/liberalism. Finally we will arrive to an overall conclusion aimed at discussing the main argument on specific and blocked modernization (diversification) of unions that is reflected in both stalled transitions into adulthood and persistence of low fertility. Based on comparative statistical data (Kuhar and Reiter, 2010) and our research, we come to a tentative argument that there are obviously predominantly structural reasons which are responsible for the family and fertility behavior in Serbia, primarily a lack of life opportunities and inadequate state support. Still we highlight value dimensions depicted here as personal inconsistencies (mismatch of traditionalism and modernism), which though not as important as socio-economic, work behind the scene hampering faster future transformations.

4 Some leading local sociologists and feminists coined the term of 're-traditionalization' of Serbian family (Milić, 2004, 2010, Blagojević, 2012, etc).

5 Although a thorough (multi - layer) analysis of fertility and family transformation as well as the underlying causes (material standards, institutionalist and idealist change) has been performed through by using various sources and data (CoE, ILO, UNICEF, European Value Survey and World Value Survey, EVS/WVS 1999/2001) for all ex-Yugoslav countries by Kuhar and Reiter (2010) 


\section{Theoretical framework}

The paradigm of second demographic transition (SDT), (Leastheaghe, 2010; McDonalds, Macura and Haug, 2005; Leastheaghe and Moors; 2000, etc) is usually deployed to explain major population change in contemporary advanced market economies by way of weakening of the ('bourgeois') family, a trend which is caused by (second) modernization, increased independence of women (in sexuality, economic wellbeing, personal freedom, gender performance) and major cultural shifts (secularization, individualization), (Fokkema and Liefbroer, 2008:1354) ${ }^{6}$. Liefbroer (1999, cf Corijn and Klijzing, 2001:5) has pointed out five major shifts in the economic and social structure related to SDT: the expansion of education, the increase in labor force participation of women, economic developments, the creation and then revision of welfare state and changes in economic factors. These structural developments were followed by cultural shifts, identified by Liefbroer (ibidem) such as: the decrease in normative controls of behavior, increased individualization and re-emergence of feminism.

The stronger the welfare state the greater the impact of SDT (the case of Northern and Western Europe). Conversely, countries with prevailing pro-familism and weak welfare mechanisms experience less of SDT (case of Mediterranean countries), (Di Giulio, and Rosina, 2007).

Three main features of the Mediterranean model are prominent (Fokkema and Liefbroer, 2008; Ule and Kuhar, 2008). Firstly, young adults stay in the parental home for a protracted period and enter marriages directly, without a phase of living on their own, in cohabiting unions, etc. Secondly, entry into marriage coincides with conception and first birth, indicating that it is the momentum when individual becomes mature or adult, no matter whether young person leaves parental home or continues to live with family of procreation (Petrović, 2004; Tomanović and Ignatovic, 2004; Ignjatovic, 2009). This makes the countries of Southern Europe renowned for a 'kinship alliance family pattern' (Sobotka, 2008:173). In particular childbearing is postponed and parenthood is treated as a great responsibility, both of which lead to very low fertility rates (TFR of 1.28 in Greece, of 1.23 in Italy and of 1.20 in Spain), (Fokkema and Liefbroer, 2008:1355). With regards to Serbia, population behavior is close to Mediterranean model with very low fertility rates (TFR in 2010, 1.40), delayed entries into marriage, protracted living with parents and transition into adulthood for both man and women. The postponement of family formation takes part until the ages of 31-35, when majority of young people eventually reach their (residential or psychological) separation from a family of origin (Tomanović, et al, 2012).

When considering post-socialist transition countries it seems difficult to place them as a unique group within the SDT trajectory (Coleman, 2005; Philipov and Dorbritz, 2003; Stankuniene and Maslauskaite, 2008; Sobotka, 2008, Petrović, 2011; Kuhar

6 In this paper we focus on union formation and avoid discussing the other dimensions of SDT concerning ageing, mortality trends, immigration, etc. 
and Reiter, 2010). They are following diverse and specific paths of SDT, determined by their structural (economic and social) changes, as stated by the 'crisis paradigm' (Philipov and Dorbritz, 2003). Secondly, the ideational crisis caused by the destruction of state socialism is significant in determining family changes in these countries (ibid). Sobotka argues that countries in transition demonstrate some common but also some particular features of SDT pattern (2008:193). These are: 1) The late occurrence of many behavioral and value changes typical of the transition, especially those related to alternative living arrangements; 2) The speed at which many features of this transition emerged during the 1990s; 3) The importance of structural and economic factors, especially in the early stage of the transition; and 4) The importance of disadvantaged social groups in the spread of some of the new types of family behavior, especially non-marital childbearing and, in many cases, unmarried cohabitation.

Following Sobotka's argument we can understand the rising portion of mothers of children born out of wedlock in Serbia as 'unwilling vanguards' of new, liberalized behavior under conditions of social deprivation, which is common among countries behind the former Iron Curtain (Sobotka, 2008:171). "Whereas lower educated individuals often embrace values that can be characterized as rather traditional, they also frequently manifest family behavior associated with the transition, such as nonmarital childbearing, high partnership instability, and high prevalence of long-term cohabitation" (ibid.:171). Similarly Perelli - Harris at al (2010) apply the pattern of deprivation (POD) as a leading paradigm which fills the gap of the second demographic transition theory. Namely although the latter explains the change in familial behavior related to social and economic improvement and ideational shifts of second modernization and post-materialism, it does not sufficiently take into account disadvantages linked to globalization in terms of economic uncertainty, poverty, restricted access to social welfare and lower levels of education for many social groups, since 1980s and 1990s. Although the proponents of SDT concept accentuated higher educated women and social groups as the forerunners, the reality is that cohabitation and extramarital childbearing has become more common among less educated in most countries of Europe ever since 1970s (except in Italy and southern European countries with overall low prevalence of the phenomenon). Therefore it seems that deprivation has been more suitable paradigm that allows better interpretation of greater likelihood of conceiving and giving birth to children in cohabitation and out of marriage. The question arises as to why women with less secure livelihood, possessing lower level of resources (material, economic, social, cultural), living in unstable partnerships decide to give birth? As Perelli - Harris advocates, 'becoming a mother' is 'a way to find a meaning of life', so these women 'grab eagerly at the surest source of accomplishment within their reach' (Perelli-Harris, B., et al, 2010:797). To the contrary, higher educated women opt for marriage, looking for stability, which makes them to delay family building, because of investments in personal reflexive biographies (prolonged education, career building, etc) and quest for suitable partner. Cohabiting couple usually lack resources to convert their relationship into marriage, hence Perelli - Harris et al (2010:797) come to the following conclusion: A wish to have a child combined with financial obstacles for getting married and less secure relationship creates negative connection of education and childbearing in cohabitation. By way of building her own future around mother- 
hood, without counting on a father of her child and her partner, a woman gains chances for self actualization and social respect in a globalized world of permanent uncertainty and risks (ibid).

\section{Data and methods}

Our analysis is founded on two main sources of data, which will be combined: official statistics and results of two surveys, carried out by the Institute for sociological research of the Faculty of Philosophy, University of Belgrade in 2003 and 2008. Therefore the main method is quantitative (descriptive statistics) and secondary analysis ${ }^{7}$.

The sample of the population investigated in 2003 was nationally representative and included 1635 households (Milić, eds, 2004), represented by an adult member. The questionnaire was very extensive and covered a wide array of topics in two main domains: structural changes related to PST (process of privatization, economic survival strategies among urban and rural actors, social stratification, etc) and coping strategies of families and households (economic strategies, housing strategies, marriage and family behavior and transformation, parenthood and ageing).

Another sociological survey undertaken in 2008 treated topics related only to family transformation in Serbia. The sample consisted of 1212 households (Milić, eds, 2010). It was constructed to be nationally representative for two groups of families of 'younger stage' and 'older stage' couples (those who had entered unions 1-5 years and 15-20 years prior to the survey). A complex questionnaire was constructed, covering different topics (interactions within families, intergenerational cohesion and conflicts, value orientations, social and cultural capitals of individuals and families, etc).

\section{Results: Blocked de-standardization of partnerships}

Analysis of empirical evidence combined with demographics (census and vital data) revealed that marriage has been the predominant life style of Serbian population. Thus as many as $63.3 \%$ of respondents of the survey were married, followed by never married (17.6\%) and widowed (12.3\%), while divorced were the least numerous (5.4\%), (Table 1). A substantial downward trend of married population has also been evidenced in census data, along with a mild and somewhat stronger increase in the respective shares of the divorced and the widowed, while the number of the unmarried registered the highest growth with a leap of full 4-5\%. Marriage decline is due to its postponement and rise of never married, all of which, combined with persistently low fertility and prolonged longevity of overall population results in the aging of marriageable generations.

${ }^{7}$ Besides these two surveys, we also took into account the results of other colleagues' empirical works, whenever necessary, in order to boost our interpretations. Results of our qualitative research on cohabitations carried out in 2002 will also be partially mentioned. 
Table 1.

Serbian population, by marital structure, 2003

\begin{tabular}{|c|c|c|c|c|c|c|}
\hline & $\begin{array}{c}\text { Never } \\
\text { married }\end{array}$ & Married & Divorced & Widowed & Others* & Total \\
\hline$\%$ & 17.6 & 63.3 & 5.4 & 12.3 & 1.4 & 100.0 \\
\hline$\%$ & \multicolumn{7}{|c|}{ Census data } \\
\hline $\mathbf{1 9 9 1}$ & 20.0 & 67.3 & 3.6 & 9.1 & $/$ & 100.0 \\
\hline $\mathbf{2 0 0 2}$ & 24.8 & 60.5 & 4.2 & 10.5 & & 100.0 \\
\hline
\end{tabular}

Source: Calculated on the basis of the 2003 empirical research and census data, Statistical office of Republic of Serbia

Table 2.

Partnership status of respondents, Serbia, 2003

\begin{tabular}{|c|c|c|c|c|c|}
\hline & & \multicolumn{3}{|c|}{ Cohabitations } & \\
\hline & Steady Dating & $\begin{array}{c}\text { Premarital } \\
\text { cohabitations }\end{array}$ & $\begin{array}{c}\text { Post-marital } \\
\text { cohabitations }\end{array}$ & $\begin{array}{c}\text { With children } \\
\text { born out of } \\
\text { wedlock }\end{array}$ & Total \\
\hline$\%$ & 1.9 & 0.8 & 0.6 & 0.8 & 4.1 \\
\hline
\end{tabular}

Source: Same as Table 1.

The survey from 2003 introduced a wider concept of partnership other than usual four categories used in Serbian censuses ${ }^{8}$ which enabled us to estimate the frequency of non-marital unions. Additional concepts covered three forms: 1) 'steady dating'; 2) cohabitations; and 3) cohabitations with a child(ren) born out of wedlock. As few as only 4\% of all respondents reported living in non-marital unions (table 2). Among the latter, 'steady dating' was the most numerous (1.9\% out of $4 \%)$. Cohabitations were less numerous and they included almost equal shares of premarital $(0.8 \%)$ and post-divorce forms $(0.6 \%)^{10}$. Cohabitations with children born out of wedlock were the rarest $(0.8 \%)$.

This finding of rare practice of alternative unions confirmed our proposition of blocked or stalled transformation of a conjugal-family paradigm. Qualitative research of upper three forms of partnership carried out in 2002 in Belgrade, disclosed that

\footnotetext{
8 Only the last census in 2011 introduced cohabitations. The results haven't however been presented yet when this text has been worked out.

9 As Sobotka and Toulemon propose (2008), this concept is similar to LAT. However we deem the previous one as better reflecting unwilling co-residence with parents and lack of freedom of choice to live on one's own or with a partner, i.e. separately.

10 Census data in 2002 revealed exactly the same share of cohabitations (1.6\%), the figure that was derived from the share of households consisted of non-relatives.

* There were $1.4 \%$ kinship based households, but without a family nucleus. The discrepancy in figures between census and empirical data stem from the fact that the main subject of census collection data is the individual, while our research tackled a household. Besides, the most recent data from census 2011 were still unavailable while writing this paper.
} 
these unions were 'trial marriages', whose proponents were young adults up to their $30 \mathrm{~s}^{11}$. These unions can be characterized as quasi-modern, since it was only their form that indicated some shift while in their essence they were highly traditional, with asymmetric gender roles and patriarchal perspectives when planning future life-course of both men and women. More specifically the whole system was centered predominantly on (future) parenting of a couple and less on reflexive biographies of partnership (Bobić, 2003).

The increase of never married, combined with the low share of non marital partnerships reinforce the argument on protracted transitions to adulthood, which is similar to Slovenia and other Mediterranean countries, as well (Ule and Kuhar, ibid.). When asked about the reasons for non-marrying and/or postponing family formation, most interviewees claimed a lack of material resources and housing on one hand and the absence of a 'proper' partner on the other. Almost none opted for non-marriage as a permanent life style (0.5\%). Authors also underlined independent housing as a major precondition for childbearing, then the education and employment status of youth in the third place (Kuhar and Reiter, 2010).

Due to structural and institutional barriers, Serbian young people are faced with a lack of chances and choices, particularly in their 20s and even 30s, which is, inter alia, reflected in the absence of diversity of living arrangements, and therefore, standardized transition into adulthood, pressure to delay and postpone events. The housing transition is blocked because a vast majority of young adults are living with their parents or relatives, which is hampering their family formation process ${ }^{12}$. Another structural barrier is a shortage of available social housing opportunities. In 2005 the state introduced the subvention credit lines to facilitate purchase of apartments by young couples (younger than 35), but, up to date, this chance was utilized by only $4 \%$, while only some $7 \%$ can afford to rent dwelling in a private sector, because of high unemployment, lack of stable and well paid jobs, economic crisis in 2008, etc.

Transition from education into employment is also very unfavorable (Labor Force Survey, 2011, cf. Mojić, 2012:307). According to official data of the National Employment Agency of the Republic of Serbia, unemployment rates for young generations are permanently around 50\% throughout 2000s. In 2011, activity rate for the work force (15-64) was 58.9\%, with employment rate 45.5\%, while unemployment rate was $22.9 \%$. When speaking of generations aged $15-24$ and $25-34$, activity rates were

11

the case study design encompassed 30 couples, the sample based on theoretical saturation principle. It proved the hypothesis of cohabitations as trial marriage or a last phase in a courtship (Mills, M, 2000), a style that was mostly familiar among urban intelligentsia, young, well educated young man and women, who altogether with their families of origin and informal network possessed a high human and social capitals (Prinz, 1995).

12

Another representative sociological survey carried out in 2000 demonstrated that $47 \%$ of young, married couples start their unions living with parents, regardless of their economic standard and social position and 37\% in their own apartment. However in as many as $90 \%$ of those living on their own, it was enabled by the support of parents and/or relatives (Petrović, 2011). Case study on cohabiting couple undertaken in 2002 in Belgrade showed that they mostly lived in apartments or dwelling of parents or grandparents and relatives, and were prone to enter marriage around 30 once they decide to have a baby (Bobić, 2003). 
28.1\% and $77.8 \%$ respectively, employment rates $14.1 \%$ and $54.2 \%$ and unemployment rates 49.9 and 30.3\%, respectively.

Higher education has also become a far reaching goal for many young people in Serbia. Therefore, while in countries of developed Europe, majority of their counterparts invest in higher education and human capital accumulation, this strategy is hardly accessible in Serbia. Namely as many as 39\% of children whose fathers are members of the elite (politicians, managers, etc) will retain the same position, while the chances of the lowest class (manual workers and farmers) to climb up the social ladder onto the top of it are minor (2,2\% and 7.9\%). If we follow datasets for the period 1989 - 2003 - 2012, we can realize that social classes have been shrinking and closing, with an increased rate of slipping to lower positions, due to economic crisis and negative growth. Self reproduction of higher class and professionals (upper middle) is evidenced (Cvejić, 2012). The education does not operate as a channel of social promotion. Instead of it, combination of social, cultural and economic capitals of family of procreation is acting as a broad avenue. There are some stipends and credits for secondary and high education, but as research reveals, their beneficiaries become (again) children from the upper social classes, since they have better grades, which appear to be the main precondition for their admission (Tomanović, 2010, Tomanović et al, 2012). Since higher resources of a family of procreation have a crucial importance for school success of children, those deprivileged or from an underclass (lower education and social capital, impoverished, disabled, immigrants, minority groups, Roma, in particular) are mostly excluded.

Social biographies of young people in Serbia are created within very unfavorable societal context, with almost lack of support of institutional mechanisms and the state and the massive reliance on informal networks, the latter being a part of Mediterranean and Southern European cultural area (Tomanović, et al, 2012:312).

However, despite these obstacles, as stated above, there is an increase of extramarital childbearing - a transitional phenomenon registered in other post socialistic countries. A relevant source of evidence comes from extensive demographic analyses (Penev and Stanković, 2010a and 2010b). Their findings confirm our previous results that vast majority of these children were born by single mothers, i.e. women who do not have/live with a partner. The number of children who were legally recognized by their biological fathers has been varying in Serbia, from more than half in 1960s, to less than 30\% in 1990, with slight increase in 2000s ( $41.4 \%$ in 2004). The crucial argument to the claim that these children were residing with lone mothers is very low rates of entering into legal unions (marriages) of these women. Namely, as few as 6.2\% unmarried mothers in Vojvodina and only $1.7 \%$ in Serbia, central part, married the father of their children, which is several times rarer compared to $1960 \mathrm{~s}$ (31.2\% and $14.3 \%$ respectively). As to the characteristics of mothers of children born out of wedlock (Penev and Stanković, 2010b) the highest likelihood to give birth has a younger generation of women, 21 years, on average. The child is usually the only one and these women mostly come from rural areas and lower social strata (either unemployed or maiden) with predominantly primary or secondary education ${ }^{13}$.

$\mathbf{1 3}$ The share of the rural population in Serbia in 2009 is estimated to be quite high, $41.75 \%$ (RZS) 
The European research carried out in eight countries (Germany, France, Italy, UK, Netherlands, Norway, Austria and Russia) has also confirmed this tendency of less educated, who face greater precariousness due to processes of globalization, economic uncertainties and shrinking of social protection to opt for extramarital childbearing, regardless of partnership as the only way of self realization and meaning of life (Perelli - Harris, et al., 2010; Petrović, 2011). It seems that disadvantaged and deprived social groups, women in particular, with less cultural, social and human capital, adapt themselves to the shifting social milieu that cannot be controlled for in any other way except by this personal choice.

\section{Conservativism vs. (weak) liberalism}

Changes in dominant preferences are recognized as one of the underlying societal causes in both SDT and POD paradigms. Therefore we decided to include the empirical evidence on value profile of Serbian population.

Respondents/couples investigated in the survey 2008 were presented with a list of 14 statements on: family, marriage, masculinity, femininity and children's well-being, and were asked to select one among 5 options (on a Lickert type scale) that best fitted their viewpoints. The range of their responses varied from 'strongly agree', to 'mostly agree', 'don't know', up to 'mostly disagree' and 'strongly disagree'. Some of the main results are presented in tables 3 and 4 .

Table 3

Gender roles and unions, attitudes of respondent/partner

\begin{tabular}{|c|c|c|c|c|c|}
\hline \multirow{2}{*}{ Statement $^{* *}$} & \multicolumn{2}{|c|}{$\begin{array}{l}\text { Level of agree- } \\
\text { ment* }^{*}\end{array}$} & \multirow{2}{*}{$\mathbf{p}$} & \multirow{2}{*}{$\underset{\text { V }}{\text { Cramer's }}$} & \multirow{2}{*}{$\begin{array}{l}\text { Chi- } \\
\text { square }\end{array}$} \\
\hline & Male & Female & & & \\
\hline $\begin{array}{l}\text { A woman is fulfilled only once she be- } \\
\text { comes a mother }\end{array}$ & 47.6 & 64.7 & 0.000 & 0.212 & 54.503 \\
\hline $\begin{array}{l}\text { It is natural and self evident that a man has } \\
\text { more sexual freedom than a woman }\end{array}$ & 26.1 & 14.1 & 0.000 & 0.254 & 77.905 \\
\hline $\begin{array}{l}\text { If only one spouse/partner is employed } \\
\text { than it is more natural to be the husband }\end{array}$ & 63.2 & 51.2 & 0.000 & 0.171 & 35.242 \\
\hline $\begin{array}{l}\text { For a happy child it is important that both } \\
\text { mother and father live together and raise } \\
\text { it up }\end{array}$ & 82.6 & 70.6 & 0.000 & 0.144 & 24.951 \\
\hline Marriage is an outdated institution & 20.2 & 26.1 & 0.000 & 0.134 & 21.773 \\
\hline $\begin{array}{c}\text { Married people are generally happier than } \\
\text { unmarried ones }\end{array}$ & 31.2 & 19.8 & 0.000 & 0.139 & 23.391 \\
\hline $\begin{array}{l}\text { It is good that men and women are equal } \\
\text { but men should have the last word }\end{array}$ & 39.5 & 15.6 & 0.000 & 0.331 & 131.420 \\
\hline
\end{tabular}

Note: Levels of agreement are calculated by summing up the shares of those who 'strongly agree' and 'mostly agree'

Source: own calculations

*** Due to the lack of space, a list of 14 statements has been halved to only 7 where statistically significant links between variables have been disclosed. 
The apparent slow down of the transformation process in Serbia has been reflected in the analysis demonstrated in tables 3 and 4. Firstly, it is important to emphasize that there were no significant discrepancies between sub-samples of 'early stage' and 'late stage' couples, which we found pretty unexpected. The only difference, not so strong, though, was registered regarding the attitudes toward divorce. Namely, slightly more 'late stage' couples (55.6\%) advocated for a divorce in case when a couple cannot find a solution of their conflicts, compared to $43.2 \%$ of 'early stage' ones. These attitudes could also mirror the onset of shifts, when considering a modest rise in divorces (divorces per 100 marriages) which has been noticed recently. Besides, family instability related to second demographic transition might have been initiated through a rise of marriage breakdown intertwined with a delay of the first unions and increase of cohabitation (Lesthaeghe, 2010). The lack of differences in attitudes among two groups of couples could also be interpreted by way of the including the interpretation gained through case study of transformation of partnerships (Bobić, 2003). The latter qualitative study disclosed that cohabitations were trial marriages tending to transform into legal ones when a first child was to arrive. It has been depicted as the momentum when partners give up their previously practiced (post)modernism in terms of: gender equity, women's career prospects, etc and the whole dyad system becomes asymmetric and child centered eventually. Therefore a lack of major discrepancy in between two marital cohorts might not be a surprise, although, of course, more investigation of the issue is definitely needed.

(Pre)-modern preferences of the respondents have been reflected in ideals of a complete conjugal family, as well as femininity and masculinity. Liberal or (post) modern orientations, although modest, are also present when speaking of sexual freedoms, authority and adoption of non marital unions.

As to the gender differences, females showed more conservative views when focusing on a motherhood as a major act of self actualization. More than half of them (64.7\%) advocated for the statement 'a woman is fulfilled only once she becomes a mother'. As many as $2 / 3$ of them consider complete family as a precondition for a happy childhood and more than half of them still idealize a 'husband provider and wife care giver' model (51.2\%). However, it seems that patriarchy has been challenged. Twice less wives compared to husbands are likely to admit greater sexual freedom for male (14.1\%), and as many of them reject male authority (15.6\%). Slightly more wives than husbands consider marriage to be an outdated institution. On the contrary, it looks that more proponents of traditionalistic sentiments are found among men compared to women. Namely, husbands showed greater proneness to gender asymmetry and inequality in unions, as reflected on all the items in table 3, except for the first one.

Persisting patriarchy is also evidenced in the next table 4. Although a positive correlation in between higher resistance of traditionalism and social position has been confirmed in this survey, there is still an evident prevalence of pro-familism among elites. 
Table 4

Attitudes toward gender roles and unions, according to social strata of a couple ${ }^{14}$

\begin{tabular}{|c|c|c|c|c|c|c|}
\hline \multirow{2}{*}{ Statement } & \multicolumn{3}{|c|}{ Level of agreement* } & \multirow{2}{*}{$\mathbf{p}$} & \multirow{2}{*}{$\begin{array}{c}\text { Cramer's } \\
\text { V }\end{array}$} & \multirow{2}{*}{$\begin{array}{l}\text { Chi- } \\
\text { square }\end{array}$} \\
\hline & Low & Middle & High & & & \\
\hline $\begin{array}{l}\text { Care of children is primarily } \\
\text { a mother's duty and then a } \\
\text { father's }\end{array}$ & 65.2 & 43.5 & 22.6 & 0.000 & 0.209 & 90.186 \\
\hline $\begin{array}{l}\text { Abortion should be legally } \\
\text { forbidden }\end{array}$ & 49.2 & 29.1 & 20.8 & 0.000 & 0.144 & 43.166 \\
\hline $\begin{array}{c}\text { A woman is fulfilled only once } \\
\text { she becomes a mother }\end{array}$ & 74.2 & 59.8 & 45.5 & 0.000 & 0.144 & 42.951 \\
\hline $\begin{array}{l}\text { It is natural and self evident } \\
\text { that a man has more sexual } \\
\text { freedom than a woman }\end{array}$ & 23.1 & 22.7 & 13.5 & 0.000 & 0.131 & 35.798 \\
\hline $\begin{array}{l}\text { If only one spouse/partner } \\
\text { is employed than it is more } \\
\text { natural to be the husband }\end{array}$ & 76.9 & 62.3 & 44.1 & 0.000 & 0.172 & 61.469 \\
\hline $\begin{array}{l}\text { It is not convenient for unmar- } \\
\text { ried couples to live together }\end{array}$ & 33.8 & 16.2 & 13.1 & 0.000 & 0.146 & 43.943 \\
\hline $\begin{array}{c}\text { A pre-school child whose } \\
\text { mother is employed is likely } \\
\text { to suffer }\end{array}$ & 32.3 & 23.8 & 13.8 & 0.000 & 0.134 & 37.306 \\
\hline $\begin{array}{l}\text { For a happy child it is impor- } \\
\text { tant that both mother and } \\
\text { father live together and raise } \\
\text { it up }\end{array}$ & 87.9 & 81.1 & 70.5 & 0.000 & 0.118 & 28.665 \\
\hline
\end{tabular}

Note: Note: Levels of agreement are calculated by summing up the shares of those who 'strongly agree' and 'mostly agree'

Source: own calculations

Namely, as many as $70.5 \%$ of highly positioned couples opt for an intact nuclear family when a child's wellbeing is at stake, and there are no great differences compared to their middle and low counterparts. Almost half of couples from high strata (45.5\%) hold conservative viewpoints about women's self realization and as many of them deem 'male provider' model to be an optimal family strategy. However, when prioritizing care of minors they are three times less conservative (22.6\%) compared to their counterparts from low strata (65.2\%).

Couples from all social strata do not widely accept the model of unemployed mother, although differences persist. Almost twice more couples from lower (32.3\%)

14 Due to the lack of space we selected only statements with statistically significant links. When analyzing the dataset a synthetic variable of a social position of a couple was constructed, based on aggregated data on: housing conditions, economic status, overall income, education and occupation. 
compared to upper strata (13.8\%) accept the model, while those from the middle are in between (23.8\%). This norm of a working mother is inherited from the previous system of state socialism where the dual income was needed in order to secure wellbeing of a household.

Opposition toward non marital unions is not so strong. Slightly more than one out of three low posited partner resists them (33.8\%), while the shares of those coming from the other two strata are almost twice rarer (16.2 and $13.1 \%$ respectively). Similar results are gained when considering gender inequality through greater sexual freedom for males (see table above).

When analyzing preferences, particularly of those better off, usually depicted as vanguards or trendsetters of social change, our results however evidence ambivalence. It might be linked to socio economic turmoil, permanent uncertainty and political crisis, ever since 1990s, which contributed to creation of a normative and behavioral mismatch. Due to long lasting economic instability, prolonged and uncompleted privatization processes, frequent fluctuations in labor market, etc., partners were often unwillingly pressed to take over tasks and responsibilities in both paid jobs and care work, despite their deeply rooted gendered standards and expectations.

On the other hand, it should be stressed here that one comprehensive descriptive study of demographic change and their underlying causes in ex-Yugoslav countries has also come to an unexpected conclusion on almost lack of effect of values. Measured dimensions such as: traditionalism vs, secularism-rationalism and materialism (survival) vs. self expression have not demonstrated influence on family formation behavior, so the authors tentatively concluded that materialist determinants i.e. socio-economic background is still highly prominent (Kuhar and Reiter, 2010).

To reinforce our field results we will sum up by showing the general findings on attitudes and comparing them with other investigations. Almost equal portions of couples in our research 2008 have been classified as 'traditionalists with features of modernism' (47.1\%) and 'modernists with traditionalist residuals' (47.3\%).

Very similar results have been demonstrated in other representative surveys carried out in Serbia and western Balkans (Pavlović, 2009, Pešić, 2009, Petrović, 2011). By investigating the materialist and post-materialist orientations, Pavlović (2009) arrived to the conclusion that around $47 \%$ of the respondents represented a mixture of both. There were quite few 'core' pre-modernists (2.1\%) but also 'pure' post-modernists (3.6\%), while Pešić and Petrović have argued that, when speaking of family and gender relations, a clear decline in patriarchal orientation has been evident since the beginning of 2000, whereas those related to authoritarianism and collectivism are still prevalent ${ }^{15}$. Scholars offered the interpretation that this might probably be due to collectivist sentiments inherited from the recent socialist past, as well as cultural backgrounds and national memories.

$\mathbf{1 5}$ The traditionalism, nationalism and patriarchy were particularly strong in the 1990s. 


\section{Closing remarks}

By presenting empirical evidence and its discussion we aimed to document some specific features of ongoing family transformation in Serbia. The focus has been primarily on the change in the pattern of partnerships, because fertility decline is an almost universal (European and Western) phenomenon, while the diversification in unions is still persistent (Boh, 1987; Kuijsten, 1996; Petrović, 2011).

Compared to European countries (including those in post-socialist transition), Serbia can be identified as a 'late starter' on the trajectory of SDT (Leastheaghe, 2010; Jones, 2007). The accumulation of unfavorable processes: huge and long lasting social deprivation, low material standards of living and slow economic recovery, lack of "chances and biographic choices" (Kuhar and Reiter, 2010), all these deteriorate lives of majority of population and youth in particular. Those from the upper and middle social strata are however highly cautious about their reproductive decisions, although, unlike the rest of citizens, they widely advocate self- actualization and female emancipation. Hence their main strategy is obviously awaiting and postponement ${ }^{16}$. On the other hand, those from lower social strata and the disadvantaged adapt to structural constraints in their own way, by unwillingly embracing new, liberalized behavior such as non marital births, divorce and single parenthood. Therefore some authors argue that their behaviors reflect drives which can be better interpreted through paradigm of deprivation combined with value liberalization and permissiveness. Such value shifts have been instigated by social transition and linked with overall uncertainty and demise of protective measures from previous state socialism. Due to similar constraints, an increasing share of people who stay out of unions and childless throughout their lives has been registered in censuses 2002-2011.

Gender inequality is still prevalent, as in other countries in transition, driven by 'the patriarchally - biased socio-political systems that seemingly privilege the interests of men more than those of women' (Kligman, 1996, cf Stankuniene and Maslauskaite, 2008). Nonetheless ongoing shifts towards post-traditionalism are reflected in everyday life change and have been documented in field research. Notwithstanding individualization processes, stronger social support, state policies and proper measures have to be put in force in order to boost personal choices, female's emancipation and reconciliation of work and family for both genders and throughout the life course. Social intervention is particularly needed to enable young people's faster transition into adulthood (through employment, union formation, career pursuit, separation from families of origin, etc), if they are expected to become the frontrunners of modernization and social change.

$\mathbf{1 6}$ The sociological study on transition into adulthood in 2004 showed that young people in Serbia delay marriage until around 30 and after that they enter unions with the strong support of families of procreation (Tomanović and Ignjatović, 2004). The postponement in fertility has particularly been pronounced during the 1990s and resumed until today as a result the vast majority of newborns are children of first parity children (Raševic, 2006) 


\section{Bibliography}

1. Beck, U. and E. Beck-Gernsheim (2002). Individualization: Institutionalized Individualism and its Social and Political Consequences. London: Sage.

2. Blagojević, M. (2012). Žene i Muškarci u Srbiji: Šta nam govore brojevi? (Women and Men in Serbia. What do numbers tell us). Beograd: UN Women.

3. Blagojević, M. (2009). Knowledge Production at the Semiperiphery: A Gender Perspective. Belgrade: IKSI.

4. Bobić, M. i J. Vukelić (2011). Deblokada druge demografske tranzicije?" ("Second demographic transition deblocked?"). Sociologija, Vol LIII/No2: 149-176.

5. Bobić, M. (2010). Partnerstvo kao porodični podsistem" (Partnership as a family subsystem), in: Milić, A. (ed.). Vreme Porodica, Sociološka studija o porodičnoj transformaciji u savremenoj Srbiji. Beograd: ISI FF: 115-147.

6. Bobić, M. (2005). Transformation of Marriage - Strategies of Conservation and Delay of Changes, in: Milic, A. (ed.). Transformation and Strategies, Everyday Life in Serbia at the Beginning of the $3^{\text {rd }}$ Millennium. Belgrade: Institute for sociological research Faculty of Philosophy, University of Belgrade: 223-238.

7. Bobić, M. (2003). Brak ili/i Partnerstvo, Demografsko Socioloska studija, (Marriage and/or Partnership, Socio-demographic study). Beograd: Institut za sociološka istraživanja Filozofskog fakulteta u Beogradu.

8. Boh, K. (1987). Changes in Marital Forms and Parenting from an European Perspective, in: Shamgar-Handelman L. and P. Rossela (eds.). Alternative Patterns of Family Life in Modern Societies. Roma: Consiglio Nazionale delle Ricerche Sulla Popolazione, Collana Monografie, 1.

9. Coleman, D. (2005). Facing the $21^{\text {st }}$ century: New Developments, Continuing Problems, in: Macura, M.; A. L. MacDonald and W. Haug (eds). The New Demographic Regime, Population Challenges and Policy Responses. Geneva and New York: United Nations: 11-45.

10. Coontz, S. (2005). Marriage, a History, From Obedience to Intimacy or How Love Conquered Marriage. Viking Penguin

11. Cvejić, S. (2012). Novi trendovi u klasno-slojnoj pokretljivosti u Srbiji, Sociološka debata (New trends in social class mobility in Serbia, a sociological debate), Sociološki Klub, Srpsko sociološko društvo, 1.11.2012, Institut društvenih nauka, Beograd.

12. Di Giulio, P. and A. Rosina (2007). Intergenerational family ties and the diffusion of cohabitation in Italy. Demographic Research. http://www.demographicresearch.org/Volumes/Vol 16/14/.

13. Demographic Statistics, corresponding years, Beograd: RZS.

14. Dribe, M. and M. Stanfors (2010). Family life in power couples: Continued childbearing and union stability among the educational elite in Sweden, 1991-2005. Demographic Research, Vol. 23, article 30: 847-878. http://www.demographicresearch.org/Volumes/Vol23/30/.

15. EUROSTAT, http://epp.eurostat.ec.europa.eu/portal/page/portal/population/ data/main tables. (7.12.2011).

16. Fokkema, T. and A. A. Liefbroer (2008). Trends in living arrangements across Europe: Convergence or divergence. Demographic Research, Vol.19. http:// www.demographic-research.org/Volumes/Vol19/36/.

17. Giddens, A. (1992). The Transformation of Intimacy. Cambridge: Polity Press 
18. Jones, W. G. (2007). Delayed Marriage and Very Low Fertility in Pacific Asia. Population and Development Review, 33 (3): 453-478.

19. Kuhar, M. and H. Reiter (2010). Transformation and demographic change in the ex-Yugoslav countries - materialist, idealist, and institutionalist perspectives on reproductive trends. Annales, Ser.hist.Soc., 20 (1): 13-26.

20. Kuijsten, A. C. (1996). Changing Family Patterns in Europe: A Case of Divergence?. European Journal of Population, 12 (2): 115-143.

21. Lesthaeghe, R. (2010). The Unfolding Story of the Second Demographic Transition. Population and Development Review, 36 (2): 211-251.

22. Matković, G.; B. Mijatović i M. Petrović (2010.) Uticaj krize na tržište radne snage $i$ životni standard u Srbiji. Beograd: CLDA, Aneks 1. http://www.inkluzija.gov.rs/wp-content/uploads/2010/03/Uticaj-krize-na-trziste-radne-snage-izivotni-standard-2010.pdf. (visited 4.2.2011).

23. Mills, M. (2000). The transformation of Partnerships, Canada, the Netherlands and the Russian Federation in the Age of Modernity, Thella Thesis Population Studies.

24. Milić, A. (eds.). Vreme Porodica, Socioloska studija o porodicnoj svakodnevici u savremenoj Srbiji. Beograd: ISI FF (Family Times. Sociological Study on everyday life in contemporary Serbia).

25. Milić, A. (ed.) (2004). Transformacije porodice i domaćinstva - zastoj i strategija preživljavanja (Transformation of Families and Households - Strategies of Conservation and Delay of Changes), in: Milić, A. (ed.). Društvena Transformacija i Strategije Društvenih Grupa: Svakodnevica Srbije na Početku Trećeg Milenijuma. Beograd: Institut za sociološka istraživanja Filozofskog fakulteta u Beogradu: 317-347.

26. Miletić - Stepanović, V. (2011). Proširena porodica u Srbiji. Beograd: ISI FF (Extended Families in Serbia. Modernization of the Family and Social transformation in Serbia at the turn of the Millenia).

27. Oláh, L. Sz. and E. M. Bernhardt (2008). Sweden: Combining childbearing and gender equality. Demographic Research, http://www.demographic-research. org/Volumes/Vol19/28/ DOI: 10.4054/DemRes.2008.19.28.

28. Pavlović, Z. (2009). Is there a Sociodemographic model of Acceptance of POstmaterialist Values? Case of Serbia. Sociologija, Vol LI/No2.

29. Philipov, D. and J. Dorbritz (2003). Demographic consequences of Economic Transition in Countries of Central and Eastern Europe. Strasbourg: Council of Europe Publishing.

30. Salvini, S. and D. Vignoli (2011). Things change: Women's and men's marital disruption dynamics in Italy during a time of social transformations, 1970-2003. Demographic Research, 24 (5). http://www.demographic-research.org/Volumes/Vol24/5/. DOI: 10.4054/DemRes.2011.24.5.

31. Penev, G. i B. Stanković (2010a). Trendovi vanbračnih rađanja u Srbiji u drugoj polovini 20. i početkom 21. veka u širem evropskom kontekstu. Stanovništvo, No1. Beograd: CDI IDN (Trends of extramarital childbearing in Serbia in the second half of the 20th and the beginning of 21st century in wider European context): 1-24.

32. Penev, G. i B. Stanković (2010b). Karakteristike vanbračnih rađanja u Srbiji u drugoj polovini 20. i početkom 21. veka. Stanovništvo, No2. Beograd: CDI IDN (Characteristics of Extramarital Births in Serbia in the second half of the 20th and the beginning of 21st century): 1-23. 
33. Petrović, M. (2011). Promene bračnosti i porodičnih modela u postsocijalističkim zemljama: Zakasnela i nepotpuna ili specifična Druga demografska tranzicija. Stanovništvo, br 1. Beograd: CDI IDN (Changes in Marital Behavior and Family Patterns in Post-socialist Countries: Delayed and Incomplete or Specific Second Demographic Transition): 53-78.

34. Pongratz, M. and Zs. Spéder (2008). Attitudes towards Forms of Partnership", in: Höhn, Ch.; D. Avramov and I. Kotowska (eds.). People, Population Changes and Policies, Lessons from the Population Policy Acceptance Study - Volume 1. Springer: $93-113$.

35. Rašević, M. (2006). Odlaganje rađanja u optimalnoj dobi života - osnovna demografska cena 1990tih u Srbiji. Demografski pregled, br 21. Beograd: Ministarstvo rada, zapošljavanja i socijalne politike i CDI IDN. (Postponement of births in the optimal life time - the main demographic cost of the 1990s in Serbia).

36. Roseneil, S. and S. Budgeon (2004). Cultures of Intimacy and Care beyond 'The Family'. Current Sociology, March 2004, 52 (2): 135-159. SAGE Publications. (London, Thousand Oaks, CA and New Delhi) DOI: 10.1177/0011392104041798

37. RZS. http://webrzs.stat.gov.rs/WebSite/Public/PageView.aspx?pKey=80. (1.12.2011).

38. Sobotka, T. (2008). The Diverse Faces of Second Demographic Transition in Europe. Demographic Research, Overview chapter 6, Vol. 19 (8): 171-224.

39. Stankuniene, V. and A. Maslauskaite (2008). Family Transformations in the PostCommunist Countries: Attitudes Toward Changes, in: Hohn, Ch.; D. Avramov and I. Kotowska (eds.). People, Population Change and Policies, Lessons from the Population Policy Acceptance Study - Volume 1. Springer: European Studies of Population: 113-137.

40. Tomanović, S. et al (2012). Mladi - naša sadašnjost. Istraživanje socijalnih biografija mladih u Srbiji (Young People are present. The Study on Social Biographies of Young People in Serbia). Beograd: ISI FF i Čigoja štampa.

41. Tomanović, S. i S. Ignjatović (2004). Mladi u tranziciji: Izmedju porodice porekla i porodice opredeljenja ('Young people in Transition: Between family of procreation and orientation'), in: Nikolic, M. i S. Mihajlovic (eds.). Mladi zagubljeni u tranziciji. Beograd: CPA: 39-64. 
Izvorni znanstveni rad

Mirjana Bobić

Filozofski fakultet Sveučilišta u Beogradu, Beograd, Srbija

e-mail:matildab@eunet.rs

\section{Specifična (blokirana) postsocijalistička transformacija životne zajednice u Srbiji}

\section{Sažetak}

Tekst se bavi zaustavljenom transformacijom životne zajednice u kontekstu postsocijalističke tranzicije. Empirijski su dokazi utemeljeni na službenoj statistici i reprezentativnom sociološkom istraživanju o kohabitaciji i obitelji nakon 2000. godine. Cilj je rada bio opisati opće tendencije i predložiti moguću interpretaciju rezultata terenskog istraživanja. Najprije predstavljamo analitički okvir koji se sastoji od dviju glavnih teorija/paradigmi - (specifična) druga demografska tranzicija (SDT) i deprivacija (POD). Ispitivanjem i kombiniranjem različitih izvora, pokušali smo bolje osvijetliti specifični, zaustavljeni ili veoma spori proces individualizacije u Srbiji. Glavni zaključak je da je moguće identificirati sljedeće promjene: odgađanje stupanja u brak te rađanja djece za veliku većinu populacije te izrazit porast broja izvanbračne djece nakon 1990. Ovo drugo je osobito vidljivo među mlađim ženama nepovoljnog položaja (slabijeg obrazovanja, nižeg socijalnog statusa, iz ruralnih sredina ili manjih mjesta), koje su niti u braku niti u kohabitaciji. S druge strane, produžena je tranzicija mladih ljudi u period zrelosti. Strukturne i institucionalne barijere sputavaju njihov izbor ponašanja i pluralizaciju obrazaca života, što je vidljivo među njihovim vršnjacima diljem razvijene Europe i u bivšoj Jugoslaviji, s izuzetkom Slovenije. Patrijarhat i solidarnost bazirana na rodbinskim vezama opstaju u uvjetima teške ekonomske situacije, niskog životnog standarda i zakašnjelih europskih integracija.

Ključne riječi: životna zajednica, Srbija, postsocijalistička tranzicija, mladi ljudi, rodbinska solidarnost. 